
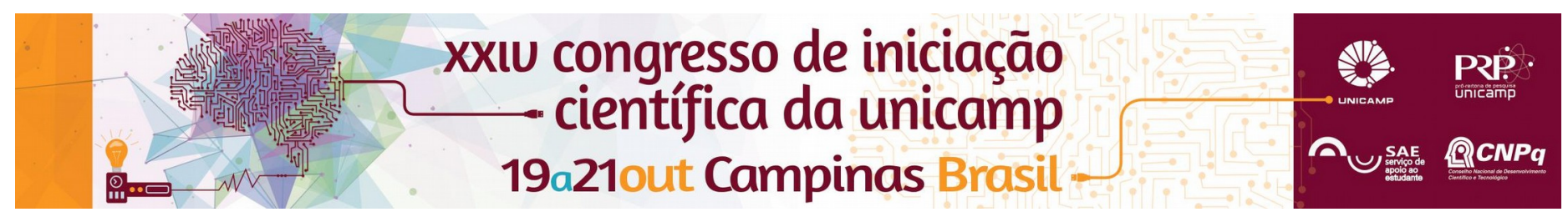

\title{
Monitoramento de Movimentos Verticais em Obras de Engenharia Utilizado Tecnologia GNSS Através de Simulação
}

\section{Prof. Dr. Jorge Luiz Alves Trabanco, Tuyra Moura da Silva*.}

\section{Resumo}

O monitoramento da movimentação de obras de engenharia é um fator importante na garantia da segurança e controle das estruturas, a fim de evitar colapso ou problemas que a obra possa apresentar. Para tal fim, o uso do GNSS (Global Navigation Satélite System) tem se mostrado de grande utilidade na determinação de tais movimentos, garantindo dados com alta precisão, além de ser um recurso com vantagens significativas, tais como a possibilidade de operar independente das condições meteorológicas e aos custos relativamente baixos na aquisição de seus receptores. Este projeto de pesquisa tem como intenção demonstrar a eficiência dessa tecnologia no monitoramento de estruturas verticais.

\section{Palavras-chave:}

GNSS, Controle de Estruturas, monitoramento.

\section{Introdução}

O GNSS tem sido empregado rotineiramente para a determinação de coordenadas e no monitoramento de deformações (verticais e horizontais) em obras de engenharia.

Essas determinações podem ser feitas de duas maneiras: por posicionamento absoluto ou relativo. No primeiro caso o receptor GPS é instalado no ponto a ser averiguado e suas coordenadas são determinadas a partir dos satélites (no mínimo 4), quando se utiliza efemérides precisas esse posicionamento é denominado PPP (Posicionamento Preciso por Ponto). Já no segundo caso são utilizados pelo menos dois receptores, onde ao menos um é fixo, com coordenadas conhecidas, e os demais receptores são posicionados nos pontos a serem monitorados, sendo assim, as coordenadas são determinadas a partir do ponto fixo.

No Brasil, essas bases fixas são disponibilizadas pelo IBGE, proporcionando ao usuário um receptor de alto desempenho que ele não precisará adquirir e instalar, essas bases compõem a RBMC (Rede Brasileira de Monitoramento Continuo).

Nesse projeto foi estudada e quantificada a variação da altitude na estação de Cananéia pertencente a RBMC.

\section{Resultados e Discussão}

São disponibilizados pelo IBGE arquivos com o posicionamento da estação de Cananéia a cada 24 horas pelo método de Posicionamento Preciso por Ponto, sendo assim, para esta pesquisa foram coletados dados da estação de Cananéia entre 2012 e 2015.

Além disso, o IBGE disponibiliza uma descrição da estação, em que são fixadas suas coordenadas oficiais,

Tomando essas informações como base, os dados do posicionamento da estação por dia foram processados e comparados com a informação que consta na descrição da estação, para assim avaliar a precisão do método e dos equipamentos.

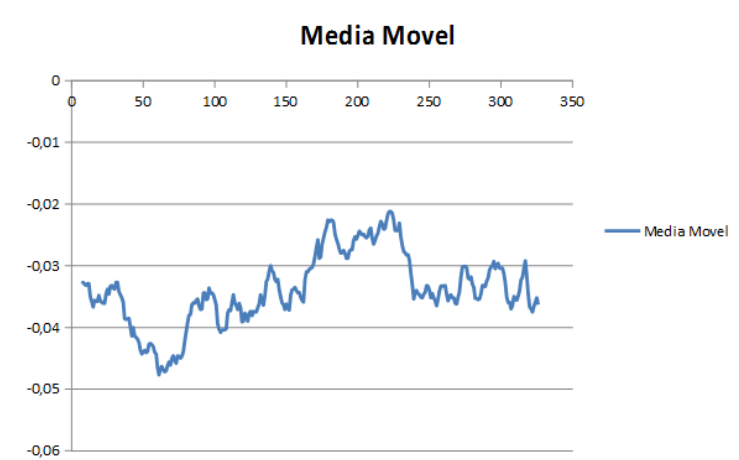

Figura 1: Média móvel da diferença entre a altura da descrição e as alturas obtidas pelo PPP durante o ano de 2013, em centímetros.

\section{Conclusão}

A análise dos dados tornou possível a avaliação da estação de Cananéia quanto a confiabilidade de suas informações para os usuários, verificando assim a estabilidade da estação e a movimentação que ela sofre graças aos efeitos de maré e ao deslocamento da placa Sul-americana.

Dessa forma, nota-se que o funcionamento da estação é satisfatório, mesmo com algumas perdas e falhas de informação que ocorrem em alguns períodos.

\section{Agradecimentos}

Agradeço principalmente ao Prof. Dr. Jorge Luiz Alves Trabanco pela oportunidade de participar de um projeto como esse e também pela dedicação empregada ao me orientar, aos técnicos do Departamento de Geotecnia e Transportes (DGT) da FEC, pela ajuda prestada nos trabalhos de campo e ao mestrando Fábio Luiz Albarici pela colaboração quanto a obtenção de dados para a pesquisa.

1 Segantine, P. C. L. GPS. Sistema de Posicionamento Global. Universidade de São Paulo. Escola de Engenharia de São Carlos. São Carlos. SP. 1999. Blackwell, 1987.

2 MONICO, J. F. G. Posicionamento pelo NAVSTAR-GPS Descrição, Fundamentos e Aplicações - São Paulo. Editora UNESP, 2000. 287p. 